\title{
Short-term consequences of nutritional depression on foraging behaviour of dark bush-crickets Pholidoptera griseoaptera (Orthoptera: Ensifera)
}

\author{
STEFFEN HAHN and GRIT KUNERT \\ Institute of Ecology, Friedrich-Schiller-University Jena, Dornburger Strasse 159, 07743 Jena, Germany; \\ e-mail: Steffen.Hahn@uni-jena.de, Grit.Kunert@uni-jena.de
}

Key words. Foraging, malnutrition, animal diet, body mass, protein consumption, scavenger, carcass, compensatory feeding

\begin{abstract}
Temporary malnutrition during juvenile development often negatively influences the life-history decisions of adults. Hence, individuals should avoid this effect by compensatory feeding on the limited resource when the food situation improves. In a feeding experiment, bush-crickets (Pholidoptera griseoaptera) responded to nine days depression of animal food supply by increasing their feeding activities on insect carcasses when a full-nutritional diet was available. As a short-term reaction, treated individuals of both sexes took 3.4 times more food from carcasses $(0.084 \mathrm{~g} / 9 \mathrm{~h})$ than control individuals. The increased carcass intake levelled off at $0.025 \mathrm{~g} / 9 \mathrm{~h}$ after an interval of nine hours, indicating that bush-crickets can rapidly compensate for an experimentally increased demand for animal diet. The general daily carcass intake of male and female bush-crickets was $0.07 \mathrm{~g}$ fresh weight, corresponding to $16.4 \%$ of the bush-cricket's body mass. Carcass intake and body mass development was correlated over the complete period ( $7 \mathrm{~d})$, but no correlation was found for the time of short-term reaction. We conclude that animal diet is essential for the growth of dark bush-crickets. They were able to compensate for short depressions in animal food supply by increasing feeding frequencies and feeding rates of the limited resource. Hence, bush-crickets can cope with short periods of limited animal food supply, e.g. periods of rainfall, which regularly occur in their natural habitat.
\end{abstract}

\section{INTRODUCTION}

In omnivorous animals a well-balanced mixture of food of vegetable and animal origin is often essential for optimal individual growth and development, because different sources contain specific and essential nutrients like amino acids or vitamins. Food shortage in general, and restrictions in parts of the diet spectrum, can lead to an increased requirement for food of the limited resource and hence will affect individual foraging behaviour and diet choice.

In grasslands of the temperate climate zone, omnivorous insects like bush-crickets and grasshoppers are assumed to be more affected by a shortage in animal diet than by a restriction of potential food plants, because the latter are normally superabundant. Also, considering the high mobility of these insects, a shortage of appropriate vegetation can be excluded. Animal food for omnivorous or carnivorous insects occurs mainly in two forms: either as other living arthropods, which have to be actively preyed upon, or as carcasses. A temporal limitation of animal food supply for insects is likely early in the season, in times of cold and wet weather, or due to a generally low presence of prey species. Arthropod carcasses are a highly attractive food resource for scavenging insects (Köhler et al., 2002). The main consumers of insect cadavers in the grasslands and rangelands of the northern hemisphere come from a variety of arthropod orders, e.g. wasps, ants (Hymenoptera), grasshoppers (Orthoptera: Caelifera) and bush-crickets (Orthoptera: Ensifera) (Lockwood, 1989; Köhler et al., 2002).

Animal protein supply is crucial for many bush-crickets and crickets (reviewed in Gwynne, 2001), e.g. for successful moulting and reproduction in mole crickets (Godan, 1961, 1964) or provisioning and growth in wart-biters (Nagy, 1950; Cherrill, 1989). In Europe, the majority of bush-cricket species (Tettigoniidae) show, at least temporarily, carnivorous feeding behaviour. They can consume a variety of taxa, ranging from the larvae of butterflies and beetles to aphids and flies (reviewed in Ingrisch \& Köhler, 1998). Some evidence of a more or less selective animal protein uptake comes from laboratory feeding experiments and a few field observations. Although a general requirement for an animal diet can be assumed, understanding of a specific diet requirement for juvenile and adult development with the onset of reproduction in bush-crickets remains very poor.

We investigated the adaptive foraging behaviour and animal food demand of the dark bush-cricket Pholidoptera griseoaptera (De Geer), a common bush-cricket species of forest clearings, fallows and semiarid grasslands in Central Europe. Dark bush-cricket larvae regularly occur in May and June; their adult moult is normally finished during July (Köhler, 1989). The omnivorous dark bush-cricket regularly feeds on herbs, grass and insects (larvae and adults), which are taken alive or consumed as carcasses (Harz, 1957; Hahn \& Kunert unpubl.).

We experimentally altered animal food demand of cagereared bush-crickets to check for direct changes in their foraging behaviour after a time of animal food limitation. Thereby we addressed the following hypothesis: If dark bush-crickets strongly depend on animal food they should respond rapidly to shortages of animal food in their actual food supply. This might be compensated for by increasing either the intake rate of animal food after the end of the limitation period or the frequency of general feeding.

\section{MATERIAL AND METHODS}

A total of 28 individuals (19 females, 9 males) of the dark bush-cricket Pholidoptera griseoaptera (De Geer) were captured in July 2001 at semiarid calcareous grassland near Jena, Germany. All individuals were in the last larval stage (L7). We randomly selected 10 females and all 9 males for the treatment groups; the remaining 9 females were assigned as the control group. For a period of nine days the bush-crickets were reared in separated groups of up to five individuals in cages and under laboratory conditions (treatment groups: $5+5$ females, $5+4$ males, control: $5+4$ females, cage size: $30 \times 30 \times 40 \mathrm{~cm}$ ). 
The treatment groups were fed daily with a mixture of pure vegetable diet (herbs: clover Trifolium sp., everlasting pea Lathyrus sp.; grass: meadow fescue Festuca sp., cocksfoot Dactylis sp., and rye grass Lolium sp.). The control group received a full nutritional diet mixture equal to food availability under natural conditions (herbs, grass and animal food, Harz, 1957, Ingrisch, 1976). As source of animal food we offered four grasshopper carcasses (mainly Chortippus sp.) per day and cage, which were killed by freezing immediately before use. After these nine days under the experimental diet regimes we separated all individuals into individual cages; none of the bushcrickets showed signs of cannibalism or damage caused by other individuals. For the following seven days we offered a full nutritional diet with vegetable food (grass and herbs) and animal food (two freshly killed grasshoppers per cage). To secure a permanent fresh food supply we renewed grasshopper carcasses immediately after feeding by a bush-cricket or at least after $12 \mathrm{~h}$. Plants were replaced every $24 \mathrm{~h}$. The complete feeding experiment was executed under lab conditions with natural light regime.

To distinguish between short-term effects and long-term effects of animal carcass shortage on the feeding behaviour of bush-crickets we divided the experimental time under fullnutritional diet regime into three parts: Period 1 from the start to $9 \mathrm{~h}$ after exposure to full nutritional diet (short-term), Period 2 from $10^{\text {th }} \mathrm{h}$ to $33^{\text {rd }} \mathrm{h}$ (intermediate) and Period 3 from $34^{\text {th }} \mathrm{h}$ to the end of the experiment (171 $\mathrm{h}$ after exposure; long-term).

\section{Foraging activity}

The behaviour of each bush-cricket was observed after exposure to a full-nutritional diet by 27 spot observations every 20 min during Period 1, 14 spot observations during the following $24 \mathrm{~h}$ (Period 2), and 20 spot observations during the last $138 \mathrm{~h}$ of the experiment (Period 3). The following behavioural classes were recorded: resting (no feeding), feeding on vegetables, and feeding on carcasses.

\section{Feeding on carcass}

To quantify the amount of carcass taken by individual bushcrickets we weighed the offered carcass with a lab balance (Sartorius, $\pm 0.001 \mathrm{~g})$ at the start, after $9 \mathrm{~h}($ Period 1$)$ and by every renewing at least all $12 \mathrm{~h}$ (Period 2 and 3). To control for carcass mass decrease due to desiccation, we simultaneously weighed a control group of 2 dead grasshoppers, which were not exposed to the bush-crickets. The feeding rates of bush-crickets were calculated from mass differences of carcass corrected for the desiccation weight loss. All values smaller than $0.01 \mathrm{~g}$ were excluded from later analysis to reduce measurement errors. For comparing feeding rates from Period 1, 2 and 3 we calculated individual means of the amount of food taken during nine hours (g/9h).

\section{Body mass development}

At capture all bush-crickets were in the last larval stage. At the end of the experiment after 16 days 21 individuals (75\%) had reached the adult stage. To investigate long- and short-term effects of malnutrition on body mass development, all bushcrickets were measured (Sartorius balance, $\pm 0.001 \mathrm{~g}$ ) to the nearest $0.01 \mathrm{~g}$ at the beginning and at the end of Period 1 and at the end of Period 3.

\section{Statistics}

Results are presented as mean \pm Std. The observational data concerning the foraging activity were analysed using a generalised linear model (GLM, Crawley, 2002; software R version 1.8.0), simplified by removing non-significant terms (Crawley, 2002). Data of feeding amounts and body mass were analysed

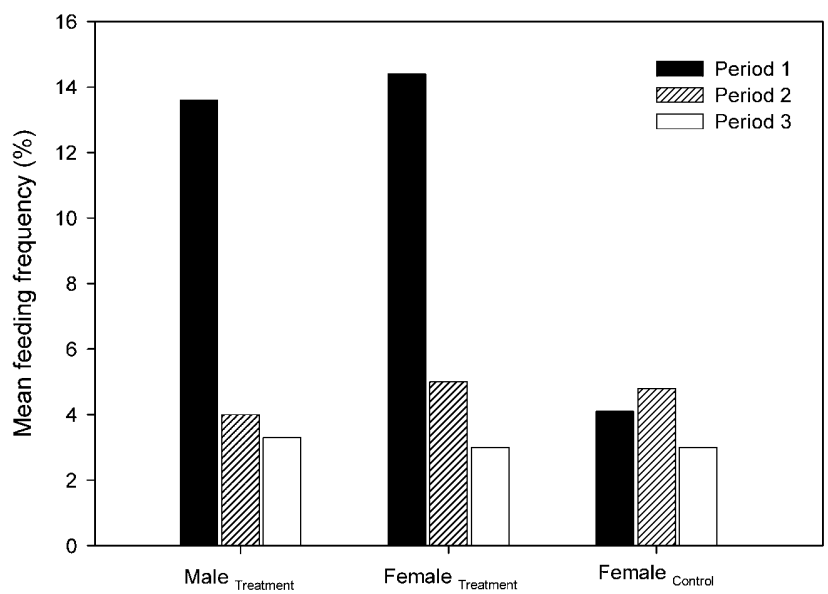

Fig. 1. Mean frequency (\%) of observations when bushcrickets were feeding. The number of observations was 27, 14 and 20 for Period 1 (black bars), Period 2 (grey bars) and Period 3 (white bars), respectively.

using ANOVA-procedures within the statistical package SPSS 11.0 .

\section{RESULTS}

\section{Foraging activity}

In Period 1 feeding behaviour was observed more often in bush-crickets from diet treatment groups than from the control group $\left(\mathrm{t}_{27}=-2.76, \mathrm{p}=0.01\right.$, Fig. 1$)$. The difference in the feeding activity disappeared during Period $2\left(\mathrm{t}_{27}=-0.09\right.$, $\mathrm{p}=0.93)$ and Period $3\left(\mathrm{t}_{27}=-0.17, \mathrm{p}=0.86\right)($ Fig. 1$)$. There was no difference in feeding behaviour between the sexes (Period 1: $\mathrm{t}_{27}=-0.20, \mathrm{p}=0.84$; Period 2: $\mathrm{t}_{27}=-0.40, \mathrm{p}=0.70$; Period 3 : $\left.\mathrm{t}_{27}=0.16, \mathrm{p}=0.88\right)$.

\section{Feeding on carcass}

During $172 \mathrm{~h}$ of the experiment (Period 1-3) all bush-crickets, irrespective of previous diet regime, were observed feeding on grasshopper carcasses. They always showed the same foraging pattern, with soft tissue from the abdomen taken first, followed by feeding on the thoracic region. The remains of abandoned grasshopper carcasses contained only the head, parts of the hind legs and the empty exoskeleton of the grasshopper's thorax and abdomen.

In Period 1 the frequency of carcass feeding was increased in both treatment groups, with higher frequencies for males than for females (Table 1). Additionally, the amount of food they had taken from the carcass was greater in Period 1 (for males treatment: $\mathrm{F}_{2,23}=5.64, \mathrm{p}=0.01$, for females treatment: $\mathrm{F}_{2,21}=74.05, \mathrm{p}=0.001$;

TABLE 1. Numbers of recorded feeding events of bush-crickets feeding on grasshopper carcasses. Feeding was measured directly by spot observation and indirectly by carcass weighing. Period refers to the experimental time after exposure to full nutritional diet with Period 1: 0-9 h, Period 2: 10-33 h and Period 3: with 34-172 h.

\begin{tabular}{|c|c|c|c|c|c|c|}
\hline \multirow[b]{2}{*}{ Period } & \multicolumn{3}{|c|}{ Observation } & \multicolumn{3}{|c|}{ Carcass weighing } \\
\hline & $\begin{array}{l}\text { Male } \\
\text { treatment }\end{array}$ & $\begin{array}{c}\text { Female } \\
\text { treatment }\end{array}$ & $\begin{array}{c}\text { Female } \\
\text { control }\end{array}$ & $\begin{array}{l}\text { Male } \\
\text { treatment }\end{array}$ & $\begin{array}{c}\text { Female } \\
\text { treatment }\end{array}$ & $\begin{array}{c}\text { Female } \\
\text { control }\end{array}$ \\
\hline 1 & 14 & 9 & 0 & 10 & 7 & 2 \\
\hline 2 & 3 & 1 & 0 & 12 & 17 & 6 \\
\hline 3 & 4 & 2 & 2 & 48 & 50 & 57 \\
\hline
\end{tabular}




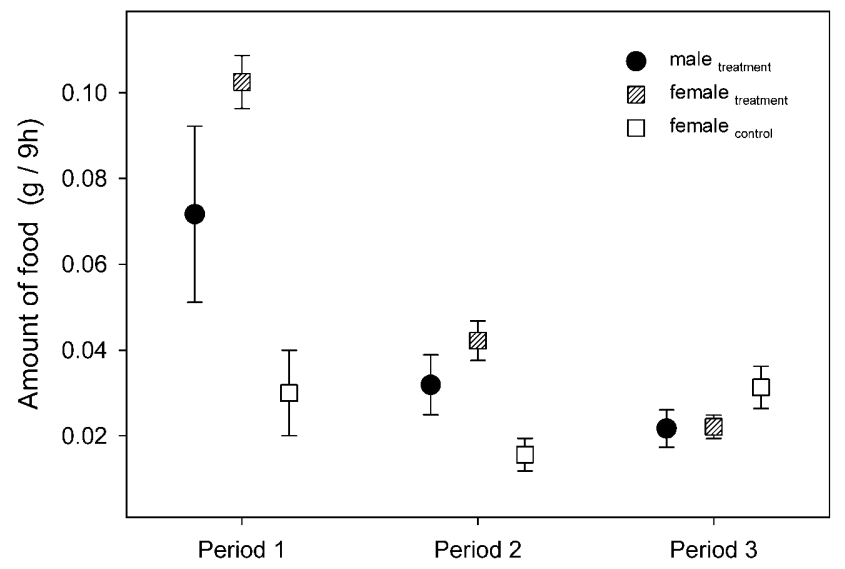

Fig. 2. The amount of food taken by bush-crickets feeding on grasshopper carcasses at different experimental periods after a 9 day period of the experimental food regime. Filled circles and grey squares represent males and females previously reared with a non-animal protein food regime, respectively. Unfilled squares symbolize females from a full-diet food regime containing insect carcasses (control group). Values are given as means per $9 \mathrm{~h} \pm \mathrm{SE}$. For time division (Period 1-3) see Methods.

Fig. 2) and averaged $0.084 \pm 0.013 \mathrm{~g} / 9 \mathrm{~h}$ without difference between the sexes $\left(\mathrm{t}_{8}=-1.43, \mathrm{p}=0.20\right.$, but test power $=0.1$; Fig. 2). From Period 2 frequency (Table 1) and quantity of carcass feeding in both treatment groups levelled off to similar values like in females of the control (Fig. 2). Females control had taken equal amounts of carcass in all experimental periods $\left(F_{2,17}=2.73, p=0.10\right)$. At Period 3 the amount of carcass fed by an individual bush-cricket averaged $0.025 \pm 0.013 \mathrm{~g} / 9 \mathrm{~h}$ (group difference: $F_{2,27}=1.77, p=0.19$ ).

In total mean carcass intake of a dark bush-cricket was $0.48 \pm 0.185 \mathrm{~g}$ during 7 days (group difference: $F_{2,27}=0.23$, $\mathrm{p}=0.80$ ), corresponding to a consumption of animal food of $0.07 \pm 0.028 \mathrm{~g}$ per individual and day.

\section{Body mass development}

At the beginning of the full-nutritional diet regime (Period 1) mean body mass averaged $0.31 \pm 0.065 \mathrm{~g}$ (range: $0.17 \mathrm{~g}-0.40 \mathrm{~g}$; Table 2) without any differences between experimental groups (body mass: $\mathrm{F}_{2,27}=0.77, \mathrm{p}=0.47$; body mass corrected for body size with body mass $* 100$ / femur length: $\mathrm{F}_{2,27}=1.42, \mathrm{p}=0.26$ ).

During Period 1 in both treatment groups mean body mass increased (for males: $0.020 \pm 0.03 \mathrm{~g} / 9 \mathrm{~h}$, for females: $0.042 \pm 0.033 \mathrm{~g} / 9 \mathrm{~h}$ ), whereas body mass of control females remained nearly stable $(-0.001 \pm 0.028 \mathrm{~g} / 9 \mathrm{~h}$, differences between experimental groups: $F_{2,28}=4.7, p=0.02$ ). There was no correlation between body mass development and carcass

TABLE 2. Mean body mass (g) of dark bush-crickets measured at the start of full-nutritional diet regime (Period 1) and after 7 days (end of Period 3). Treatment groups were reared with pure vegetable diet before, the control group received vegetables and animal food. Data are means \pm Std.

\begin{tabular}{lccc}
\hline & Male $_{\text {treatment }}$ & Female $_{\text {treatment }}$ & Female $_{\text {control }}$ \\
\hline Start of Period 1 & $0.32 \pm 0.039 \mathrm{~g}$ & $0.29 \pm 0.069 \mathrm{~g}$ & $0.33 \pm 0.080 \mathrm{~g}$ \\
End of Period 1 & $0.34 \pm 0.045 \mathrm{~g}$ & $0.33 \pm 0.052 \mathrm{~g}$ & $0.32 \pm 0.068 \mathrm{~g}$ \\
End of Period 3 & $0.38 \pm 0.097 \mathrm{~g}$ & $0.40 \pm 0.084 \mathrm{~g}$ & $0.50 \pm 0.118 \mathrm{~g}$ \\
\hline
\end{tabular}

feeding rates either in both treatment groups or in the control (Pearson correlation $\mathrm{r}$ : all $\mathrm{p}>0.05$ ).

After seven days at the end of Period 3 body mass increase was $0.005 \mathrm{~g} / 9 \mathrm{~h}$ (median) without significant differences between groups (Kruskal-Wallis: $\mathrm{H}_{2,28}=2.41, \mathrm{p}=0.30$ ). The average daily mass gain amounted $0.017 \pm 0.013 \mathrm{~g}$, corresponding to $4 \%$ of a mean body mass of $0.43 \mathrm{~g}$ (Table 2 ). The body mass development over the complete three periods was positively related to the amount of carcass taken (partial correlation controlled for treatment groups: $\mathrm{r}=0.85, \mathrm{p}=0.001$, $\mathrm{df}=25$ ).

\section{DISCUSSION}

In oligophagous arthropods malnutrition, e.g. a restriction in animal food supply may cause reproductive disadvantages such as lower fecundity, deferred maturity and lower mating success, which directly affect fitness (Simmons \& Gwynne, 1993; Fox \& Mousseau, 1996; Gwynne, 2001, 2004). Hence, individuals should quickly compensate for a temporal food or nutritional depression to ensure their reproduction success during the single reproduction period.

The dependency of omnivorous insects on animal protein varies between life stages, e.g. animal protein demand peaks before moulting into the adult stage and during maturity phase in the first days of the imago stage (Kerkut \& Gilbert, 1985). During such times, individuals should quickly adapt their foraging behaviour to the actual food supply, even as food conditions are improving after a period of malnutrition. Therefore, individuals compensate either by an enhanced general feeding activity and/or by feeding more of the limited source if this is available again (Simpson \& Abisgold, 1985; Raubenheimer \& Simpson, 1990; Simpson et al., 1990).

We experimentally restricted animal food supply to dark bush-crickets Pholidoptera griseoaptera, a common species in European grasslands, to induce responses in terms of adapted foraging behaviour after their exposure to a suboptimal diet. In accordance with expectations bush-crickets which had previously sustained an animal food restriction for nine days responded with increased general feeding activity during the first period of full-nutritional diet, but not for the following periods. Furthermore, these individuals fed more often on offered insect carcass than those with continuous access to animal rich food. Immediately after offering a full nutritional diet containing vegetables and grasshopper carcasses the amount of carcass taken by treated males and females was about 3.4 times greater and contributed to $25 \%$ of the average body mass. This intensified feeding activity in individuals of both sexes only occurred in the first hours. After a nine hours interval the carcass feeding rates of treatment individuals already dropped down to an overall average of $0.07 \mathrm{~g}$ carcass per day which indicates a very rapid compensation for the increased animal diet demand. Because further higher carcass feeding rates did not appear in the experimental groups, we can exclude that other intrinsic factors such as limited gut space or protein digesting enzymes were responsible for this short-term reaction.

Hence, bush-crickets suffering nine days of animal diet malnutrition immediately responded to better food conditions and showed rapid compensation for the experimentally enlarged animal food demand. The experiment had no statistically significant effects on intermediate and longer term changes in the foraging behaviour of bush-crickets, clearly supporting the idea of rapid compensation for temporary malnutrition and therefore, the potential of the individuals to cope with short-lasting poor food conditions. Simultaneous body mass measurements paralleled the observation of foraging behaviour with a significantly increased body mass increase of treated individuals in the first 
period. This clearly supports our conclusion of short-term adjustment of carcass feeding behaviour in bush-crickets. Furthermore, body mass increase was highly correlated with the amount of carcass taken during the complete experimental time; verifying the assumption that body condition in bush-crickets also depends on diet quality (Gwynne, 2004).

The availability of high quality food during larval development can affect both sexes (Godan, 1964; Hunt et al., 2004) Food with high protein content and/or high energetic value can favour faster development and early moulting into the imago stage (Hunt et al., 2004; Perkins et al., 2004). This advantage in time can be crucial for reproduction, because bush-cricket males emerging early in the season have higher mating and reproductive success than males moulting late to the imago stage (Wedell \& Ritchie, 2004). If protein diet enables larvae growth to large final (imago) size, males with high protein diet have higher mating success either via the production of larger nuptial gifts (spermatophylax) and/or higher re-mating rates (Gwynne, 2004). In females, there is some evidence that high quality food is a prerequisite for high fecundity, e.g. females of the Grey bush-cricket Platycleis albopunctata feeding only on vegetables laid 15\% fewer eggs than females feeding on full-nutritional diet containing animal protein (Waltert, 1994). Because egg production, e.g. vitellogenesis, greatly increases females' protein demands (Kerkut \& Gilbert, 1985), sufficient animal protein supply via animal diet or nuptial gifts guarantees high reproductive success. Furthermore, food availability might also indirectly influence reproductive success, not only in the adult stage. For instance, in the grasshopper Sphenarium purpurascens, larger females have a higher reproductive success than smaller ones (Del Castillo \& Nunez-Farfan, 2002). Since imago size depends on the size of the last instar, the growth of the final instar, which depends on food availability, is important.

Additionally, the feeding experiment highlights the role of bush-crickets as carcass consumers on a community level: all dark bush-crickets had fed on grasshopper carcasses during the course of the experiment, indicating that this resource belongs to the natural food spectrum of this species. They preferred abdominal parts of grasshopper carcasses and hence the energetically rich fat-body and ovaries. The daily demand for insect carcass per individual was $0.07 \mathrm{~g}$ fresh weight. In Central Europe dark bush-crickets occur in densities of approximately 1 individual per $2 \mathrm{~m}^{2}$ (Steinhoff, 1982; Detzel, 1985), resulting in a daily carcass demand of $350 \mathrm{~g}$ fresh weight per day and hectare. Assuming a mean duration of $80 \mathrm{~d}$ for the last larval plus imago stage (Köhler, 1989) a population of 5000 individuals per 1 ha will consume $28 \mathrm{~kg}$ fresh carcass per season. Taken into account that $72 \%$ of 29 Central European bush-cricket and cricket species (Tettigonioidea and Grylloidea) are omnivorous (reviewed in Ingrisch \& Köhler, 1998), the estimation of carcass consumption reflects clearly that bush-crickets have a key function as predators or scavengers in grasslands.

ACKNOWLEDGEMENT. We are very thankful to G. Köhler for inspiration and S. Bauer, D. Raubenheimer and an anonymous referee for critical comments on the manuscript. A. Thieme, C. Stephan and C. Meyenberg assisted us with high enthusiasm and accuracy in the lab.

\section{REFERENCES}

Cherrill A. 1989: The diet of the wart-biter, Decticus verrucivorus (L.). Bull. Brit. Ecol. Soc. 20: 115-118.

Crawley M. 2002: Statistical Computing. John Wiley \& Sons, West Sussex, $761 \mathrm{pp}$.
Del Castillo R.C. \& Nunez-Farfan J. 2002: Female mating success and risk of pre-reproductive death in a protandrous grasshopper. Oikos 96: 217-224.

Detzel P. 1985: Die Auswirkungen der Mahd auf die Heuschreckenfauna von Niedermoorwiesen. Veröff. Naturschutz Landschaftspflege Bad-Württ. 63: 253-258.

Fox C.W. \& Mousseau T.A. 1996: Larval host plant affects fitness consequences of egg size variation in the seed beetle Stator limbatus. Oecologia 107: 541-548.

GodAN D. 1961: Untersuchung über die Nahrung der Maulwurfsgrille (Gryllotalpa gryllotalpa L.). Z. Angew. Zool. 48: 341-357.

Godan D. 1964: Untersuchung über den Einfluß tierischer Nahrung auf die Vermehrung der Maulwurfsgrille (Gryllotalpa gryllotalpa L.). Z. Angew. Zool. 51: 207-223.

Gwynne D.T. 2001: Katydids and Bush-Crickets: Reproductive Behavior and Evolution of the Tettigoniidae. Cornell University Press, Ithaca, NY, 344 pp.

GwYNNE D.T. 2004: Sexual differences in response to larval food stress in two nuptial feeding orthopterans - implications for sexual selection. Oikos 105: 619-625.

Harz K. 1957: Die Geradflügler Mitteleuropas. Gustav Fischer Verlag, Jena, 494 pp.

Hunt J., Brooks R., Jennions M.D., Smith M.J., Bentsen C.L. \& Bussiere L.F. 2004: High-quality male field crickets invest heavily in sexual display but die young. Nature 432: 1024-1027.

INGRISCH S. 1976: Vergleichende Untersuchungen zum Nahrungsspektrum mitteleuropäischer Laubheuschrecken (Saltatoria: Tettigoniidae). Entomol. Z. 20: 217-224.

INGRISCH S. \& KöHLER G. 1998: Die Heuschrecken Mitteleuropas. Westarp Wissenschaften, Magdeburg, 460 pp.

Kerkut G.A. \& Gilbert L.I. 1985: Comprehensive Insect Physiology, Biochemistry and Pharmacology. Vol. 2. Pergamon Press, Oxford, 505 pp.

KöHLER G. 1989: Zur Phänologie, Abundanzdynamik und Biotopbindung rasenbewohnender Laubheuschrecken (Saltatoria: Tettigonioidea) im mittleren Saaletal bei Jena (Thüringen). Wiss. Z. Friedrich Schiller-Univ. Jena (Naturwiss. R.) 38: 543-561.

Köhler G., Hahn S., Reinhardt K., Wagner G. \& Ritz M. 2002: What happens with dead grasshoppers on grassland? A field experiment. Articulata 17: 33-49.

Lockwood J.A. 1989: Cannibalism in rangland grasshoppers (Orthoptera: Acrididae): attraction to cadavers. J. Kans. Entomol. Soc. 61: 379-387.

NAGY B. 1950: Adatok a Decticus verrucivorus L. (Orthopt.: Tettigon.) táplálékszükségletének kérdéséhez. [Short note on the food requirement of Decticus verrucivorus L. (Orthopt.: Tettigon.).] Ann. Biol. Univ. Debrecen 1: 222-228.

Perkins M.C., Woods H.A., Harrison J.F. \& Elser J.J. 2004: Dietary phosphorus affects the growth of larval Manduca sexta. Arch. Insect Biochem. 55: 153-168.

Raubenheimer D. \& Simpson S.J. 1990: The effects of simultaneous variation in protein digestible carbohydrate and tannic acid on the feeding behavior of larval Locusta migratoria and Schistocerca gregaria Forskal I. Short-term studies. Physiol. Entomol. 15: 219-234.

Simmons L.W. \& Gwynne D.T. 1993: Reproductive investment in bush-crickets - the allocation of male and female nutrients to offspring. Proc. R. Soc. Lond. (B) 252: 1-5.

Simpson S.J. \& ABISGOLD J.D. 1985: Compensation by locusts Locusta migratoria for changes in dietary nutrients behavioral mechanisms. Physiol. Entomol. 10: 443-452.

Simpson S.J., Simmonds M.-S.J., Blaney W.M. \& Jones J.P. 1990: Compensatory dietary selection occurs in larval 
Locusta migratoria but not Spodoptera littoralis after a single deficient meal during ad libitum feeding. Physiol. Entomol. 15: $235-242$.

SteINHOFF G. 1982: Ökologische Freilanduntersuchungen an Geradflüglern (Orthopteroidea) des Bansenberges in der Eifel. Decheniana (Bonn) 27: 100-173.
WALTERT M. 1994: Untersuchungen zur Nahrungsökologie der Westlichen Beißschrecke Platycleis albopunctata (Orthoptera: Tettigoniidae). University of Würzburg, $42 \mathrm{pp}$.

Wedell N. \& Ritchie M.G. 2004: Male age, mating status and nuptial gift quality in a bushcricket. Anim. Behav. 67: 1059-1065.

Received March 4, 2005; revised and accepted August 10, 2005

\section{BOOK REVIEW}

Basset Y., NovotnÝ V., Miller S.E. \& Kitching R.L. (eds): ARTHROPODS OF TROPICAL FORESTS: SPATIOTEMPORAL DYNAMICS AND RESOURCE USE IN THE CANOPY. Cambridge University Press, Cambridge, 2003, xvi + 474 pp. ISBN 0-521-82000-6 (hard cover). Price USD 110.00.

In retrospect, it seems incomprehensible that we would have explored the ocean depths, reached the peaks of the highest mountains and the frigid north and south poles of our planet, and walked on the moon a quarter of a million miles from Earth, long before devising ways to move about the forest canopy - a mere 46 meters away - with any but the most primitive methods. The canopy not only was closer and more tangible than these destinations, it was often in plain view. We could almost taste our quarry, or observe it through binoculars, yet it remained quite literally out of reach. The best we could do was shoot down branches to obtain plant specimens, fog the foliage with pyrethrins to sample its arthropod inhabitants and, more recently, ascend one tree at a time using mountain-climbing gear.

Why the delay in reaching the canopy? Quite simply, gravity, fear, and lack of incentive. Though gravity is our ally in reaching the ocean depths, it is a formidable obstacle when moving in the opposite direction, up. Overcoming it and remaining aloft requires extreme acceleration and sustained speed - both counterproductive to canopy research. Lack of incentive, except by biologists. Why would anyone want to go up there? It is scary. There's no money to be made there, no pearls or sunken treasure. The canopy doesn't offer the allure of great and distant adventure; it's too close to home.

Biologists, on the other hand, long suspected that the canopy was where the action was. All evidence indicated it: arthropod samples collected by fogging trees with insecticides or by raising ultraviolet and mercury-vapor light traps into the canopy with pulleys, revealed that diverse and abundant life was to be found there. That view was supported further by observations made by the few people who had reached the canopy using climbing gear, and by the well-known fact that forest gaps and forest edges - which may be viewed as mini sections of "the canopy brought to ground level" - are known to be much more productive places to collect insects than is the forest understory.

The biologist's dream was to find a gentle way to reach the tree-tops and move about freely and silently without greatly disturbing the plants and animals one wished to study. It took a leap of imagination, by the late Alan Smith (Smithsonian Tropical Research Institute, Panama), to realize that an item of existing technology, the canopy crane, could be diverted from its original use, to perform quite a different task: lift biologists into the forest canopy, and, by coordinating the crane's vertical, horizontal, and circular motions, deliver researchers to any point 